\title{
A Sociolinguistic Study of Women Representation in Rwandan Proverbs
}

\author{
Protais Niyonshima \\ RP-IPRC Musanze, P.O. Box: 226 Musanze, Rwanda
}

\begin{abstract}
In almost all communities, proverbs reflect every aspect of the social and cultural lives of people. In Rwandan culture proverbs embed wisdom, values, norms, and social restriction. As in other languages, in Kinyarwanda, proverbs are used as a tool for human communication. Kinyarwanda proverbs have certainly the features of gender as they disclose the real and normal life of Rwandans. Gender-related Kinyarwanda proverbs that value women are referred to when valuing women's role in the community. This contributes to the journey of women's emancipation that Rwanda is currently fostering. However, there are some negative proverbs that strengthen the roots of gender discrimination linked to patriarchal social norms and practices. Despite an outstanding progress in women's empowerment and gender promotion that Rwanda has made, Kinyarwanda proverbs still contribute to women exclusiveness in a way that attributes negative traits to them. Thus, the gender discrimination persists. This paper reveals the findings of a study on the socio-linguistic perspectives that explore the place and role of women and/or girls in the Rwandan society. Therefore, this paper outlines Kinyarwanda proverbs that loop women and girls in a negative perspective, and their effects in achieving Rwanda Vision 2050 goals and the Sustainable Development Goals (SDGs). This study examines 30 Kinyarwanda proverbs related to disempowerment of women and girls. They were analyzed by using the feminist theories of the Radicals and Critical Discourse Analysis by Norman Fairclough.
\end{abstract}

Keywords: Proverbs, gender equality, Vision 2050, SDGs.

DOI: $10.7176 /$ RHSS/10-24-02

Publication date: December $31^{\text {st }} 2020$

\section{Introduction}

Gender inequality is a persisting issue in many communities worldwide. From time immemorial, women have been marginalised in the Rwandan society, as it was the case in many countries in Africa. According to UNICEF (2007), gender disparity is created by society and passed on from one generation to another. Due to its deep roots in culture, gender discrimination required vigorous measures fighting for gender equality in Rwanda. Today, Rwanda is one of the Sub-Saharan African countries that has made great strides in promoting gender equality and women's empowerment, politically (having the highest number of women in parliament in the world, at 56\%), socially, economically and particularly in education.

Currently, women in different countries have gained their rights, through different mechanisms that were put into place to enhance human rights worldwide. However, the topic of women's rights always appears in the global agenda of human rights and development. In Sustainable Development Goals (SDGs), gender role is numbered five, a proof that it is a pressing issue that needs to be addressed. Women who are excluded from decision-making within families, communities, and nations are often the very targets of development programs designed to improve their lives (FIDA, 2006).

The Rwandan population is composed of mostly women, according to the recently conducted General Population and Housing Census. The figures of a survey conducted in 2012 reveal that women make up 51.8 percent of Rwandan 10.5 million inhabitants while males account for 48.2 percent. Their contribution to economic growth could be a huge input to the national economy if they are given equal space. Instead of income generating activities, many women spend most of their time in domestic activities (cooking, feeding, childbearing, etc.).

Daily life is reflected in the language used in a given society. Kinyarwanda creates and revives different aspects of Rwandan life including cultural experiences. Proverbs, as a part of Rwandan literature, portray the cultural experiences and wisdom of Rwandans. Kinyarwanda proverbs talk about both men and women, and they touch different aspects of life. The cultural representation of women in Rwanda, as it is in many societies, corroborates gender ideology and the position women have in society. Proverbs indicate clearly how women are excluded from decision making within families and communities. Yksel (1993) affirms that almost every proverb that touches on women contains a severe negation of the value of women in society.

This paper focuses on the social construction of gender in proverbs. It examines women's image portrayed through Rwandan proverbs which strengthen the roots of inequality in Rwandan society. This study talks about the major definitions attributed to "proverb" and its features and functions in society and how some of the proverbs about women undermine their potential. It also divulges some gender theories about gender roles and relations in the context of Rwandan society.

I do believe that this paper will highlight some misconceptions and stereotypes attributed to women that need 
change for an inclusive society of zero gender bias, false truths and behaviour.

\section{Theoretical background}

Proverbs are part of the cultural property of a society; they reflect the social features like traditions, habits, democracy, equality, gender, beliefs, values, etc. Therefore, through proverbs one may determine some of the features of a given society. Studies were conducted to explore the perceptions and expectations of a society reflected in proverbs, and affirmed that they are transmitted from generation to generation. Yskel (1993) opines that because of the characteristics of proverbs (rhythm, rhyme, parallelism, simple language, short form), they attract the attention of others and they are easily memorized. Thus, they are easily used and transmitted from one generation to another.

In many cultures, proverbs of women are known to be harsh and critical. They are often cited to highlight a negative side, and to undermine women. Yuskel (1993) asserts that women are perceived like evil and are compared to animals such as dogs, horses, cats, etc. Often men are portrayed in proverbs as superior. That difference between men and women shape a bad perception and negative impression towards women. Gender construction is well perceived through proverbs as they have a connection to gender roles. Otiso (2016) states that proverbs construct gender attributes by aligning the gender roles of men and women.

In fact, a language is a mirror of society; it reflects the social life of a given community. Thus, proverbs mirror society's expectations of the different sexes and are also used by men to exercise their physical power while describing women's mental and social weakness (Lakoff, 1975).

It is important to note that a man is the chief of the family in the Rwandan society, and it is prohibited for women to demonstrate their leadership potentials in the presence of men. As a Kinyarwanda proverb states it, "Ntaa nkokôkazi ibîka isaâke ihâri," (No hen shall make a cock-a-doodle-doo in the presence of cock). The latter captures the position of a woman in society. Although negative proverbs on men exist, they are however not affecting the high positions in society, they are mostly used to criticise and correct men's behaviour. In a proverb, "Umugabo mbwa aseka imbohê" (a coward laughs at a prisoner) men are advised not to laugh at someone in trouble, for tomorrow they might find themselves in the same situation.

On the other hand, women and girls are considered submissive and dependent on men. This strengthens inequality that has roots from gender roles. For instance, in Rwandan society, patriarchy has brought an ideology that describes men as natural owners of intellect, think rationally and have power to rule whereas women and girls are defined as submissive, passive and willing to be led. UNDP Rwanda (2018) states that girls and women around the globe are declaring "times up" to the patriarchal norms and misogyny that accompany gender inequality.

Closely related to the above, gender imbalance leaves a critical gap in the development journey because in most cases women are left out in the planning and implementation process of various programmes yet their contribution would be of a great asset in the society. Therefore, as women and girls remain marginalised tough issues arise, namely illiteracy, disease, starvation, poor health, loss of life to mention a few. It is important to note that domestic violence and social conflict partly stem from that gender imbalance, simply because women and girls are denied a voice in decision making by their families and the entire society. UNICEF (2007) affirms that where women have low status and are denied a voice in household decisions, they are more likely to be undernourished themselves and less likely to have access to resources that they can direct towards children's nutrition.

Researchers revealed that children learn about appropriate attitudes, and behaviour from their parents and peers. Thus, girls learn to conform to a stereotype of femininity, a learnt role of such attributes as passivity, dependence, and sentimentality (Olurundare, 1989).

This study referred to the Feminist Critical Discourse Analysis (FCDA) approach. Society is saddled with many social problems including dominance and power abuse. These are enacted and reproduced in discourse in ways that may not always be obvious (see Fairclough, 1992; Fairclough and Wodak, 1997). It is in that perspective, for example, Lazar (2007), stated that issues of gender, power, and ideology have become increasingly more complex and subtle in present times. One may say that proverbs, by their nature, present more complex and subtle understandings. Thus, by their opaque and sometimes their ambiguous meanings, proverbs often portray a hidden intended meaning, thereby making their ideological underpinnings subtle, but quite pervasive.

Obviously, proverbs can serve to sustain (hierarchically) gendered social arrangements, in which the woman is disadvantaged, and these may be presented in very subtle ways. The work of FCDA is to critique such unequal gender relations. It is in this light that the researcher found it a useful analytical approach for this study. FCDA may be considered as a subset of Critical Discourse Analysis (CDA) because, in simple terms, FCDA analysed CDA from a feminist perspective. I shall therefore briefly outline some major tenets of CDA, which are also the building blocks for FCDA.

Generally, gender discrimination hinders the respect to human rights and the growth of development. Despite the mechanisms that are coming up to promote women and girls' emancipation in Rwanda, they still lag behind in different domains. The journey is still long. 
FCDA outlines two important concepts to consider in patriarchal societies namely hegemonic masculinity and femininity. Cleary, patriarchal societies promote male domination over female. Men are seen as authority figures who hold the power, and this is seen as legitimate or largely inherent (Connell, 1987, 1995). As it is put up by Connell (1995), a hegemonic masculinity is a gender practice configuration that embodies a currently accepted answer to the problem of legitimacy of patriarchy, which guarantees or is taken to guarantee the dominant position of men and the subordinate position of women.

\section{Methodology}

In this study, two instruments were used to collect data namely interview and documentation. Interview essentially focused on the selected community elders known for their knowledge of Rwandan culture, the socio-cultural aspect in particular. For the sake of accuracy in data collection, most of the interviews held, key informants were recorded using a tape-recorder. Since the interviewees used Kinyarwanda, their views are translated into English. In addition, documentation served in getting an insight about proverbs in Rwandan culture. During this study, 30 proverbs were examined. In the past, there was a tendency to examine African proverbs that talk exclusively about womanhood to understand the role and position of women in Africa (Mbiti, 1988).

For a thorough comprehension, this study includes some proverbs about men for a better analysis between two men and women. In addition, the study followed a qualitative approach in its analysis of proverbs. Information is analysed in a descriptive manner since it captures people's experiences (Cresswel, 1998). In data analysis, the researcher wrote down the notes from the data collection process. As Hussein (2005) suggested, any study on African proverbs should start from the complex cultural, social and psychological factors that influence the production and consumption of the proverbs.

As stated by other researchers (Paltridge, 1994; Tyler, 1994), the structural simplicity of a text (proverb) may not guarantee increased comprehensibility. There is no such way to understand well the meaning of a proverb without the consideration of its historical and cultural background. For instance, a proverb "Amasuunzu sî amasakâ," (The tassel isn't the grain; i.e., Good appearance isn't necessarily riches), its meaning is linked to traditional hair style and wealth. It is obvious that there is a clear connection between language and culture.

Normally, a proverb may have different meanings depending on the context; it is difficult, therefore, to be precise in the meaning of a proverb without a context. In this study, content analysis and hermeneutics as data analysis methods were used. Hermeneutic interpretive orientation is a philosophy of human understanding and interpretation of a text (Guba \& Lincoln, 1994). The interpretative orientation was used to reveal their significance not on the surface of images and representation but in the complex ways that produce, transform and shape structural meaning.

Thus, three things were taken into consideration: Interpret a general meaning embedded in a proverb, explain the social contexts in which the proverb is used, and analyse the implications of the proverb. The ethnographic technique of cultural domain analysis, which considers text as an indicator of human experience (Tesch, 1990) was used to guide the thematic analysis of the proverbs.

During the data collection stage, a researcher got 100 proverbs related to females, they were manually extracted from the different sources by using a filter of female-related words namely birth, child, girl, marry, woman, lady, mother, work, family, and their derivatives. Thus, a total sample of 30 proverbs was analysed. After a thorough reading of the raw data, and the transcripts of the field notes, the researcher categorized or coded the data into manageable and meaningful sets of themes.

\section{Findings and discussions}

\subsection{Women considered as inferior, worthless and weak people in society}

1. Umugorê arabyîna ntâasiimbûka. (A woman can dance may not jump)

2. Ntaa nkokôkazi ibîka isaâke ihâri. (A hen cannot cluck when a cock is around)

3. Uruvûze umugorê ruvuga umuhoro. (A word of a woman is followed by a machete)

4. Ingabo y'ûmugorê iragushoora ntîigukûura. (A woman soldier opens the front line but does not fight it)

5. Umukoôbwa w'îgicûucu yiirahiira imfîizi ya sê. (A foolish girl compares herself to her father)

6. Umugorê gitô arutwa n'ûumwâanzi gicâ. (A bad woman is less worth than a dangerous enemy)

7. Umugorê w'înkoramwuuga, abishiima yîikoze muu nda. (A professional witch ends up in killing her own children)

8. Umugorê w'ûmupfû akubitirwa ku iibûga. (A bad woman is beaten in public)

9. Ubugorê sî amabêere n'îhenê irayagira. (Being a woman is not having breasts, even a goat has them)

10. Bâgutumye umurozi uheera kurî nyoko. (In a search for a witch you start with your mother)

\subsubsection{Interpretation}

Proverbs portray women as weak people who are not able to do what men can do. In addition, they affirm that women do not have smart ideas like men. Instead of good ideas, when they are given an opportunity to express themselves, they enjoy that favour and abuse it by doing harmful things. Thus, the society prefers not to give them 
full rights of participation in family and community matters, rather they make them submissive (Proverbs 1,2,3,4). Furthermore, some proverbs express the weakness of women in terms of bravery, they fear the battle. However, they cause conflicts although they know well, they will not participate and sort out the caused problems. In addition, women are seen as evil to the extent of being more dangerous than an enemy (Proverbs 5,6,7).

In return of those characteristics and behaviour, society disrespects women through the violation of their rights. Proverbs state that a woman can be beaten publicly as a punishment, this does not value women. Women are also disrespectful in different proverbs with a focus on their body parts, and bad enough they are said to be witches (Proverb 8,9,10).

\subsubsection{Implications to Rwanda Vision 2050}

The Vision 2050 of Rwanda is about ensuring high standards of living for all Rwandans by moving from today livelihood to the society everyone wants and feels proud to belong to. Achieving the national goals requires a clear involvement of all citizens. Having women considered as weak people, underestimated and neglected in various aspects including decision making leads to the failure of many projects including national plans. As Nangendo (1994) states, it is a fact that as long as women are pushed to the periphery of social, economic, and political progress, the country's development will remain stifled. Should women be involved in decision making, their children also will be involved immediately as they will be engaged from a young age.

\subsubsection{Implications to Sustainable Development Goals (SDGs)}

It has been seen in the above proverbs; women are underestimated in Rwandan society. This creates a lack of confidence and self-esteem in women. As proverbs are transmitted from generation to generation, women are taught that they are inferior to men. At a young age, young girls are taught by society that they do not matter a lot like their fellow boys. Thus, they internalize this understanding and it leads to stereotypes that impede women emancipation. As a matter of fact, they may not partake in a journey to development with those discrepancies. Consequently, women's perspectives remain inferior. This may impact negatively on the achievement of gender parity in the society. Indeed, there is no way of attaining the SDGs without an inclusive role of all citizens.

\subsection{Women considered as domestic workers, wives and caregivers}

1. Umugorê abyaara uwâawê ntaabâ uwâawê. (A woman gives birth to your child but she does not become yours)

2. Umugorê asasira uwiîshe sê. (A woman sleeps with a killer of her father)

3. Umugorê mwiizâ asegura inkôkorâ inkokô zikariinda zîbika. (A beautiful woman goes to bed till the morning) 4. Umugorê ntaajyâ kurâarika, iyô araarîtse abuza n'ûwarî kuuza. (A woman does not invite, when she invites none comes)

5. Uwiîba ahêetse aba yîigiisha uûri imugôongo. (If you steal carrying a kid on you back, you're teaching him/her) 6. Umugorê umûrika muu mbere yâandurura, aba yêereka imbeba. (A woman who lights the store when clearing table after eating she shows the rats.)

7. Umugorê urî ku mutibâ ntâaburâ umutîma. (A woman in the store does not lose heart)

8. Umugorê w'ûmupfû arya imbûto agasiga intabîre. (A dead woman eats seeds and leaves a prepared land empty)

9. Izîna ryiizâ ry'ûmukoôbwa ntîryaâmubujije kuruha. (A good name of a girl didn’t prevent her from agony)

10. Umugorê umwiita Nyîrabareenzi yaajyâ kuvooma akamena ikibiîndi. (When a woman is said to be bright, she goes to fetch water and breaks a pot.)

\subsubsection{Interpretation}

In Rwandan society, girls are taught, through informal education, to be women with the responsibilities of taking care of household affairs, as domestic workers, wives and caregivers. It is obviously observed in different home circumstances such as events, and ceremonies, one may mention, marriage, initiation, and counselling. Regrettably, through that informal education, girls are taught to secure marriage even when the marital relationship is worse and it results in domestic violence.

Proverbs assert that women are bad in the family because they betray their own family. It is as if they do love their families. Moreover, society considers them as untrustworthy people. Though they are seen as people who are in charge of domestic activities, their performance is not appreciated. Proverbs consider them as lazy (Proverbs $1,2,3,4)$.

As far as children rearing is concerned, women are pointed at to be responsible for bad manners of the children, proverbs indicate that women teach their children bad habits. In addition, proverbs say that women are not good managers of family wealth, they misuse the properties of the family. Therefore, they are not fully involved in management of the entire wealth of the family (Proverb 5,6,7,8).

Proverbs indicate that a good name of a girl has nothing to do with her agony. She is subject to suffering regardless of her potential. Even when a woman achieves a lot in her life, proverbs state that it is not a good idea to appreciate them for they will mess up other things. Therefore, they do not deserve any appreciation (Proverbs $9,10)$.

A recent national household survey found that women spent three times many hours per week on domestic tasks such as cooking, cleaning, collecting firewood, or fetching water in 2011 than men did (NISR 2012, 30). 


\subsubsection{Implications to Rwanda Vision 2050}

Despite their efforts in securing families lives, women are looked down upon in terms of the role they play in their families. Men are believed to be more intelligent than women. Oboler (1985) states that in different communities it is commonly claimed that if a woman tried to manage property, she would very likely make a mess of it.

In fact, the stereotypes oblige women to deal with domestic activities and take care of children. However, they are limited in family decision making. Only men decide for the entire family as chief of families. Connell (1987) affirms that men are seen as authority figures who hold the power, and this is seen as legitimate or largely inherent. Therefore, the work of women is not acknowledged and it discourages and limits women to play an important role in the national economy as the nation moves forwards to achieving the Vision 2050.

\subsubsection{Implications to UN Sustainable Development Goals}

Inequalities are supported by society that finds women defective and inappropriate, and instead of helping their families prosper they tend to destroy them. Consequently, women and girls bring about the stereotypes by believing that they are useless. The women are thus a subordinated group, which has resigned themselves to their secondary role as mothers and caregivers. From the implementation of MDGs, the world wanted to promote gender equality and the empowerment of women as effective ways to combat poverty, hunger and disease and to stimulate development that is truly sustainable. However, if women are nurtured as dependents, they are absolutely not empowered. Thus, meeting the SDGs' goal regarding the promotion of women is not possible when they are not involved in development-related activities. This sustains a state of male dominance over women.

\subsection{Women are marginalized}

1. Umugorê gitô arutwa n'înkiîngi. (A bad wife is less worth than a house pillar)

2. Umugorê musaangira amatâ ntîmusaangîra amâazi. (A woman, you share with her milk not water.)

3. Umugorê umwiita sheênge waarimûkuura mugakuura inkiîngi. (You compliment a woman and when you don't compliment her, you destroy a pillar)

4. Umukoôbwa bamushiima ingeendo akareenga iwaâbo. (A girl is appreciated of her manner of walking, and she passes over her home)

5. Wiirukana umugorê ugûguna igûfa ukaazana uûrimira buunguri. (You chase a woman who gnaws a bone and you bring the one who swallow it)

6. Umugorê yaryâamanye n'îkireêmba ati naambariye ubusâ ubuûndi.

(A bad woman slept with an impotent and said I've got naked for nothing)

7. Umukoôbwa aba umwê agatukiisha bôose. (A crime of one girl is for all girls)

8. Indarikira kwaambara y'ûmugorê yatâaye umugabo ku gasî. (A woman who longed for clothes left his husband in an arid place)

9. Umugorê nî nk'îhenê bazirîka ahô amatovu arî. (A woman is like a goat tied where there is acanthus)

10. Ntaa nkumî yîigaya ikibero. (There is no young unmarried girl who underestimates her beauty.)

\subsubsection{Interpretation}

Some of Rwandan proverbs marginalised women by attributing some strange features to them to underestimate them in Rwandan society. They are, therefore, pejoratively used, and women are usually discriminated against in society on grounds that they are not of good importance. Proverbs attribute negative traits to women like worthless, carelessness, gluttony, quarrels, and witchcraft that harm family members (Proverbs 1,2,3,4,5).

Proverbs also affirm the fact that women are undermined on the basis of behaviours, women are said to be sex players, and material-oriented people. They are not seen as people of good behaviours. Marginalising women makes them passive in society, and lose confidence in themselves $(6,7,8,9,10)$.

\subsubsection{Implications to Rwanda Vision 2050}

Due to cultural stereotypes, women are marginalized in many ways and limited to many opportunities. World Bank (2016) affirms that social norms can limit women's mobility and ability to network, restrict women's representation in politics and government, and be enshrined in discriminatory laws and practices.

Oppressions discourage women's involvement in national development. Women's voices are ignored by society. Not considering the role of women in the development of the country leads to persistent poverty. However, USAID (2015) mentions that a nuanced understanding of the role gender plays in efforts to end extreme poverty can lead to better results for women and girls themselves, their families, and their communities.

A journey of Rwanda to ensure high standards of living for all Rwandans by 2050 cannot be achieved, if nothing is done to involve and value women in aspects of life.

\subsubsection{Implications to UN Sustainable Development Goals (SDGs)}

The proverbs reveal hegemonic masculinity which encourages control and oppression of women. Consequently, the socialization process reflects men as superior and victimizes women. These proverbs promote differential power relations between men and women and encourage women rights abuse. Therefore, Women's dignity is compromised with the use of these proverbs. In this case, Millennium goal three of Gender equality cannot be achieved in this situation since women are not valued like men. 


\section{Conclusion}

The present study was an attempt to explore how Rwandan women are represented in proverbs, to see whether proverbs discriminate against them or not. Rwanda has made tremendous achievements in promoting women, however even the remaining parts need some interventions to integrate women in all aspects of life like their fellow men. To achieve the objectives of this study on women representation in proverbs, the researcher collected a number of proverbs from different sources to investigate women's image in Rwandan society. Proverbs tend to legitimize certain stereotypes related to women, and maintain ideologies that undermine women. The government of Rwanda, through its different programs that promote women, should endeavour to change negative mind-sets about women, and eliminate or reform the proverbs that reinforce gender parity to match with inclusive human rights.

\section{References}

Connell, R.W (1987). Gender and Power: Society, the Person and Sexual Politics. Cambridge: Polity Press.

Creswell, J. W. (1998). Qualitative inquiry and research design: Choosing among five traditions. London: Sage Publications.

Fairclough, N. (1992). Discourse and social change. Cambridge: Cambridge Polity Press.

Fairclough, N. and V. Wodak (1997). Critical discourse analysis. In: Van Dijk TA (ed.) Discourse Studies: A Multidisciplinary Introduction. London: SAGE, pp. 258-284.

FIDA, (2006). Report of a Baseline Survey on the Level of Awareness and Impact of CEDAW on rural women in Kenya. Nairobi.

Gatete, C. (2016). The Rwanda We Want: Towards Vision 2050. Presentation in Rwanda National Dialogue 2016, Kigali.

Guba, E.G. and Lincoln, Y.S. (1994). Competing paradigms sin qualitative research, in Handbook of Qualitative Research, Denzin, N.K. and Lincoln, Y.S. (eds) (Sage Publications, CA) pp. 105-17.

Hussein, W. (2005). The social and ethno-cultural construction of Masculinity and Femininity in African Proverbs. African Study Monographs.

Lakoff, R. (1975). Language and Women's Place. New York: Harper \& Row.

Mbiti, J. (1988). The role of women in African traditional religion. Cahiers des religions Africaines, 22:69-82.

Nangendo, S. M. (1994). "Daughters of Clay, Women of the Farm; Women, Agricultural Economic Development and Ceramic Production in Bungoma District, Western Province in Kenya". Unpublished PhD thesis, Bryn Mawr College.

Olorundare, Solomon. (1989). An Investigation into the "Differences" between Men and Women in Science. Ilorin Journal of Education, 9, $103-120$.

Otiso, Z. (2016). Examining the Indigenous wisdom in EkeGusii Proverbs. The University of Nairobi Journal of Language and Linguistics Vol 5: 116-129.

Paltridge, B. (1994). Genre analysis and the identification of textual boundaries. Applied Linguistics, 15 (3): 288 299.

Tesch, R. (1990). Qualitative Research: Analysis Types \& Software Tools. Bristol, PA: Falmer Press.

Tyler, A. (1994). The role of syntactic structure in discourse structure: Signalling logical and prominence relations. Applied Linguistics, 15 (3): 243-262.

UNICEF (2007). The state of the world's children 2007.

USAID (2015). Gender and extreme poverty. Washington: USAID.

World Bank (2016). Voice agency and empowering women and girls for shared prosperity. Washington: World Bank Group.

Yskel, W. (1993). Women in proverbs. Oxford University. 